\title{
Seed-density effects on germination and initial seedling establishment in eelgrass Zostera marina in the Chesapeake Bay region
}

\author{
Robert J. Orth ${ }^{1, *}$, James R. Fishman ${ }^{1}$, Matthew C. Harwell ${ }^{2}$, Scott R. Marion ${ }^{1}$ \\ ${ }^{1}$ Virginia Institute of Marine Science, School of Marine Science, 1208 Greate Road, College of William and Mary, \\ Gloucester Point, Virginia 23062, USA \\ ${ }^{2}$ Arthur R. Marshall Loxahatchee National Wildlife Refuge, 10216 Lee Road, Boynton Beach, Florida 33437, USA
}

\begin{abstract}
The influence of Zostera marina L. seed-density on germination and initial seedling success was investigated using seed-addition field experiments at 2 scales in the Chesapeake Bay region in 1999 and 2000. We first tested whether germination rates and initial seedling establishment were affected by initial seed-densities of $2.5,25,250$, and 1250 seeds $\mathrm{m}^{-2}$ within $4 \mathrm{~m}^{2}$ plots. We then tested whether plot size affects germination rates, following the hypothesis that rates of seed predation might be different in large and small plots. We broadcast seeds at a single density $\left(500\right.$ seeds $\left.\mathrm{m}^{-2}\right)$ but at a much larger plot size $\left(100 \mathrm{~m}^{2}\right.$, or 25 times the size of the small plots). In the spring following seed broadcast, seedlings were present in most $4 \mathrm{~m}^{2}$ plots (seedling densities of 0.6 to $15.4 \%$ of the number of seeds released in 1999, and 3.3 to $23.3 \%$ of those released in 2000) and in all $100 \mathrm{~m}^{2}$ plots $(4.3 \%$ to $13.9 \%$ ). Seed-density effects were not significant in 1999 or 2000, while site effects were significant in both years. The percentages of seedlings in the larger plots were similar to those in the smaller plots. These results suggest that there were no density-dependent effects on germination and initial seedling establishment, and that within the size range of plots examined in this study, such processes are not likely to be scale-dependent. The significant differences among the sites may be related to micro-topographic complexities of the bottom caused by both biotic and abiotic factors that allow seeds to be retained close to where they settle. Our data, combined with previously published data on seed dispersal and patch dynamics, stress the importance of conserving existing beds, regardless of bed size and shoot density, since these are sources of seeds that may establish new patches. The data may also help in developing strategies for the restoration of denuded sites using seeds instead of adult plants.
\end{abstract}

KEY WORDS: Seeds · Germination · Seedling establishment · Zostera marina $\cdot$ Chesapeake Bay Resale or republication not permitted without written consent of the publisher

\section{INTRODUCTION}

Processes that influence the establishment of a seedling from a seed are often diverse and complex (Wenny 2000). Several factors can account for seed losses, e.g. pathogens, predation, inter- and intraspecific competition, movement to unsuitable germination sites, or simply failed germination (Harper et al. 1965, Chambers \& MacMahon 1994). Harper (1977) viewed the landscape as a 'lattice' of safe and unsafe seed-germination sites, with seeds having to pass through an 'environmental sieve' (defined as a suite of environmental obstacles in the path of a seed from the time of release to the time of germination) before arriving at a 'safe site' (defined as a zone where seeds find the required stimuli and resources to germinate and grow, and where mortality factors are absent). Many of these factors may be density-dependent, although there is conflicting evidence of density-dependence in terrestrial seed-ecology literature (Waite \& Hutchings 1978, 1979, Cabin et al. 2000). For seagrasses, there is very little information about density-dependent 
effects on seed germination or seedling establishment (Granger et al. 2000) or about what constitutes a 'safe site' for a seagrass seed.

Zostera marina L. (eelgrass) is the most common temperate seagrass throughout the Northern Hemisphere (den Hartog 1970). Annual seed-production ranges from 6176 to 24460 seeds $\mathrm{m}^{-2}$ (Olesen 1999); however, the reported seedling numbers are actually significantly less than the numbers of seeds produced (Olesen \& Sand-Jensen 1994, Olesen 1999). In the Chesapeake Bay region, seedlings are nearly always observed each spring within seagrass beds, but also in unvegetated, shallow-water sand flats at varying distances from potential donor beds (R. J. Orth unpubl. data).

The colonization history of these seedlings is not well known, although it probably arises from the previous year's reproductive effort, as persistent seed banks are not characteristic of this species in this region (Orth et al. 2000a). In addition, small patches (1 to $3 \mathrm{~m}^{2}$ ) over $1 \mathrm{yr}$ old have been observed 1 to $100 \mathrm{~km}$ from existing beds in this region (Harwell \& Orth 2002a). We assume that these patches developed from seeds delivered by rafting reproductive shoots (Harwell \& Orth 2002a) because floating vegetative shoots are unlikely to successfully re-establish (Olesen \& Sand-Jensen 1994, Ewanchuk \& Williams 1996). Yet the level of seed input required to establish these patches is unknown, as is the subsequent mortality from density-dependent or independent processes. Olesen \& Sand-Jensen (1994) also reported numerous Zostera marina seedlings in unvegetated areas adjacent to an established bed in Denmark that developed from a seed bank of 26 seeds $\mathrm{m}^{-2}$, but seed-density processes were not determined in that study.

Density-dependent processes have not been identified relative to Zostera marina germination and early seedling survival, but could hypothetically influence germination positively or negatively. For example, if seedling-seedling interactions exist that inhibit initial development we would expect to see an inverse relationship between seed-density and initial establishment rates. Similarly, an inverse relationship might emerge if seed predators were attracted to high densities of seeds.

In the terrestrial environment, seed-predator interactions are very important, often driven by densitydependent processes (Janzen 1971, Crawley 1992, Hulme 1994, Marone et al. 2000), with both plant and predator evolving various strategies to ensure their survival by altering encounter rates. For example, plants can produce large numbers of seeds either annually or in alternate years (i.e. masting), thus ensuring that some seeds survive predation through predator satiation or starvation (Silverton 1980, Crawley \& Long 1995). Predators can adjust their foraging strategies based on the density of seeds, through either cache-hoarding, entering diapause, or migrating to sites with greater food resources (Janzen 1971). Several studies have shown that some species, such as decapod crustaceans, can feed on seagrass seeds (Wassenberg \& Hill 1987, Wigand \& Churchill 1988, Wassenberg 1990, O'Brien 1994, Fishman \& Orth 1996, Holbrook et al. 2000) and thus have the potential to influence seed-density and seedling establishment.

In this study, our primary interest was to determine if density-dependence exists for Zostera marina seed germination and initial seedling establishment. We designed seed-addition experiments (seed introduction sensu Turnbull et al. 2000) at 2 scales at several sites in the Chesapeake Bay region. At the smaller scale $\left(4 \mathrm{~m}^{2}\right)$, we tested if germination and initial seedling establishment were affected by initial seeddensities. We then tested whether germination and initial seedling establishment differed at a larger spatial scale $\left(100 \mathrm{~m}^{2}\right.$ unvegetated plots), based on the hypothesis that higher seed abundances in larger plots could either satiate seed predators, resulting in higher germination, or attract more predators, resulting in lower germination.

\section{MATERIALS AND METHODS}

Collection and storage of seeds followed procedures outlined in Orth et al. (1994). Reproductive shoots with mature seeds were harvested by hand in late May to early June 1999 and 2000, returned to the laboratory, and held in $3.8 \mathrm{~m}^{3}$, aerated, flow-through outdoor seawater tanks until seed release was complete. Seeds were subsequently sieved from decomposing plant material and held in the tanks until initiation of the experiments. A seed was considered viable if it had a rigid seed coat and a high fall velocity (Orth et al. 1994). Appropriate numbers of viable seeds were obtained via direct counts or sub-sampled estimation of sieved material.

In order to assess the viability of the seeds used in our experiments, at the initiation of each experiment 100 seeds were randomly chosen from the batch of seeds to be used in the experiments, and 10 seeds were placed in the sediment in each of 10 peat pots approximately $10 \mathrm{~mm}$ below the sediment surface. Sediments were from an unvegetated shoal area where seed experiments had been successfully conducted in previous years (Orth et al. 1994, Fishman \& Orth 1996, Harwell \& Orth 1999) and consisted predominantly of sand with a low organic content $(<1 \%)$. Peat pots were placed in outdoor seawater tanks supplied with air and continuously running seawater from the York River (following procedures of Moore et al. 1993). In Decem- 
ber 1999 and 2000, the contents of the peat pots were sieved through a $1.0 \mathrm{~mm}$ sieve. All seeds were assessed for germination, indicated by the emergence of the cotyledon (Stage 1 of Churchill 1983). We did not adjust the percentages of seedlings calculated in the experiments because factors influencing germination under laboratory conditions may be different than those in the field. The sole objective was to confirm that we had a viable batch of seeds for our experiments.

Seed experiments were initiated in the fall of 1999 and 2000, prior to the November period of seed germination (Moore et al. 1993) at several sites in the Chesapeake Bay region. All experimental sites historically supported dense stands of Zostera marina (Orth \& Moore 1984), but were either completely unvegetated or had small patches of naturally occurring $Z$. marina within a few $100 \mathrm{~m}$ of the experimental plots (Orth et al. 1999, 2000) at the time of the experiments.

We selected 10 sites in 1999 and 4 sites in 2000 to test the first question of how initial seed-densities affected germination rates (Fig. 1): $4 \mathrm{~m}^{2}$ plots were created at 4 seed-densities $\left(2.5,25,250\right.$ and 1250 seeds $\left.\mathrm{m}^{-2}\right)$ by releasing $10,100,1000$ or 5000 seeds just above the sediment surface. These densities are within the range of seed-densities found in established beds (Harrison 1993, Olesen \& Jensen 1994, Harwell \& Orth 2002b). The plot was marked with corner stakes to allow precise relocation of the plot the following spring. At each site, 3 replicates of each seed-density were established in a transect parallel to shore, with 20 and 30 m separating each seed-density plot in 1999 and 2000, respectively. In 2000, plots with no seeds were established to determine if natural recruitment was occurring or if seeds were moving among plots. All plots were arranged relative to the shore so that water depth, currents, and exposure were similar for all plots.

To address the second question of effects of scale, we broadcast seeds at a single density (500 seeds $\mathrm{m}^{-2}$ ) but at a much larger plot size $\left(100 \mathrm{~m}^{2}\right.$ or 25 times the size of the small plots) at 5 sites (Fig. 1) in 2000, resulting in a seed abundance of 50000 seeds plot ${ }^{-1}$. At the South Bay site, we established 2 plots, 1 inshore, and 1 approximately $300 \mathrm{~m}$ offshore of the first plot. Seeds were dispersed as evenly as possible by hand, by a single individual walking across the plot, similar to the method employed by Orth et al. (1994).

Assessment of seedling abundance began in midMarch of the following year, when seedlings could be observed and accurately counted. Seeds germinate in early to late November (Moore et al. 1993) and grow slowly during the winter months (when water temperatures range from 0 to $5^{\circ} \mathrm{C}$ ). We have no evidence of a seed bank for Zostera marina in this region (Moore et al. 1993, Harwell \& Orth 1999) and are confident that there were no viable, ungerminated seeds remaining in the sediment at the time of sampling. Water temperatures at the time of sampling ranged from 8 to $13^{\circ} \mathrm{C}$. Seedlings were counted using snorkel or SCUBA within the 4 or $100 \mathrm{~m}^{2}$ plots for the respective experiments, and in an additional $4 \mathrm{~m}$ perimeter surrounding the entire plot. This additional area allowed assessment of the few seedlings that appeared outside the plot. Previous experiments (Orth et al. 1994, Harwell \& Orth 1999) showed that seeds move only a few meters from where they settle on the sediment surface. We counted every seedling by placing $4 \mathrm{~m}^{2}$ quadrats divided into 16 equal-area $\left(0.25 \mathrm{~m}^{2}\right)$ cells over each plot and counting all seedlings in each cell. This yielded a total area assessed for seedlings of $100 \mathrm{~m}^{2}$ for the $4 \mathrm{~m}^{2}$ plots and $324 \mathrm{~m}^{2}$ for the $100 \mathrm{~m}^{2}$ plots. In addition, divers scanned the surrounding area; they noted almost no seedlings outside the sampled area. To ensure that counts were of actual seedlings and not multiple shoots from 1 seedling, we occasionally had to completely excavate and separate individual seedlings, or fan away the top layer of sediment, exposing the rhizomes and the original seed coat

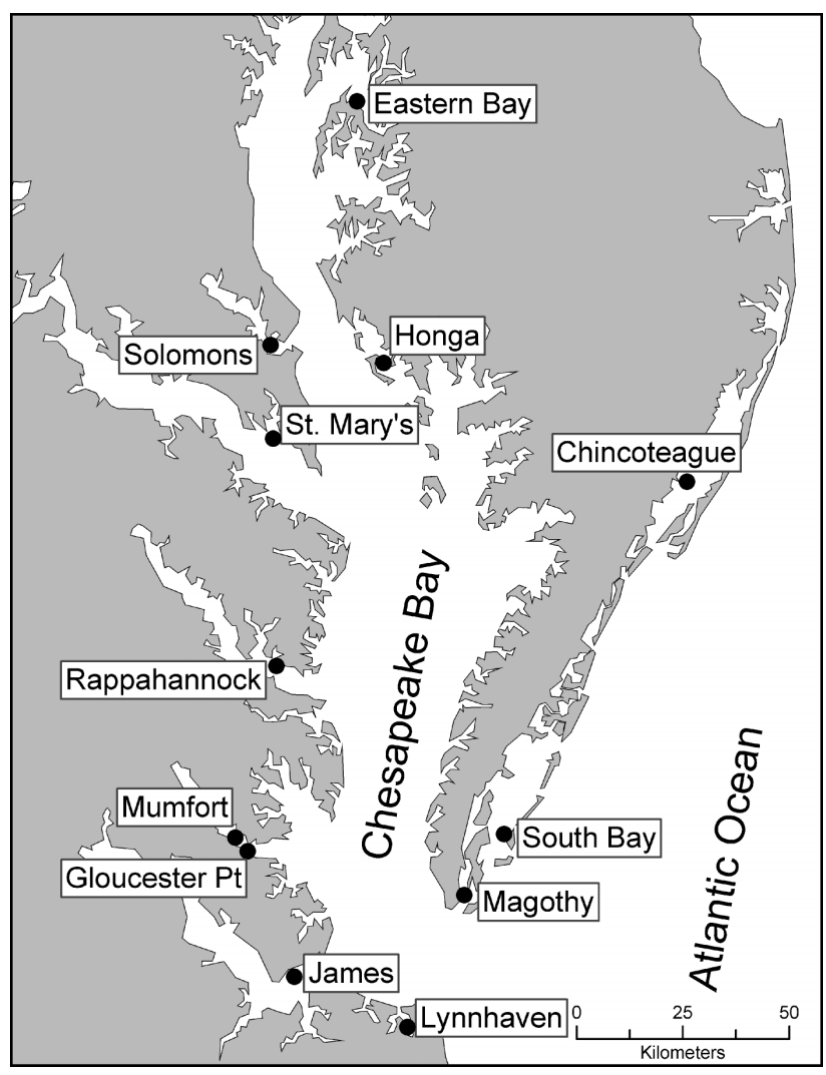

Fig. 1. Zostera marina. Location of sites where seed-density experiments were conducted in Chesapeake Bay and coastal bays 
(which can remain attached to the root/rhizome complex for at least 6 to 7 mo after germination: R. J. Orth pers. obs.). At some sites, extensive vegetative growth made counting seedlings difficult, and in these cases we recorded the number of shoots present in small areas of $<100 \mathrm{~cm}^{2}$, completely excavated the areas, examined the ratio of shoot numbers per seedling in the laboratory and calculated an estimated seedling abundance.

To ensure that the site was suitable for plant survival and growth, adult plants were transplanted into two $4 \mathrm{~m}^{2}$ plots next to the seed experiments at the same time the seed was broadcast. These shoots were harvested from a large donor bed in the York River and were planted $20 \mathrm{~cm}$ apart following the technique of Orth et al. (1999a). Survivorship of these adult plants was assessed using direct counts $30 \mathrm{~d}$ after transplanting and at the time of the seedling counts, approximately $180 \mathrm{~d}$ after the seeds were broadcast.

Additionally, 3 sediment samples were collected at each site using a small, $20 \mathrm{~cm}$ long, Plexiglas corer. The top $2 \mathrm{~cm}$ of the sample were analyzed for percent sand, silt, and clay fractions and total organic matter, except for Chincoteague Bay where the top $5 \mathrm{~cm}$ was used. Sand fractions (2000 to $62.5 \mu \mathrm{m}$ ) were analyzed by a rapid sediment analyzer, while silts and clays $(<62.5 \mu \mathrm{m})$ were analyzed by the pipette method (Folk 1980). Total organic matter was measured by drying and combusting a $10 \mathrm{~g}$ sample for $24 \mathrm{~h}$ at $550^{\circ} \mathrm{C}$, and data are presented as percent ashfree dry weight.

In the 1999 experiments we observed significantly greater than expected seed input from outside the experimental area at the Chincoteague and James River sites, despite the fact that the sites we chose had very sparse populations of Zostera marina. In addition, we noted at 1 site a higher degree of seed movement than observed previously between plots (Orth et al. 1994), and hence increased the distance between plots in the 2000 experiment. As a result, the percentages of seedlings in the low-density treatments were highly skewed due to the input of these extraneous seeds. This complicated the interpretation of low-density treatments, but the effect is trivial in the higher density treatments (e.g. 5 extraneous seeds in the lowest density treatment creates a much larger artifact than 5 extraneous seeds in the highest density treatment). Consequently, we only compared the 1000 and 5000 density treatments because of experimental artifacts in the 2 lower density treatments. In 1999 we also excluded the 2 South Bay sites located behind a barrier island. One of the South Bay sites located immediately behind a sand spit at the north end of this barrier island was completely buried by $1 \mathrm{~m}$ of sand, as several winter storms moved the adjacent sand spit over both the seed and adult plant plots. The other South Bay site was shallower than the other sites and may have been exposed at low tide, a process undoubtedly lethal to emerging seedlings. The site had very few seedlings, and all were stunted in growth, while plants in the nearby slightly deeper adult plot were present and had grown. Because of these results, the plots for the 2000 experiments in South Bay were located in a more suitable area.

For both the 1999 and 2000 data, the proportion of initial seeds that were counted as germinated seedlings was calculated for each plot, and arcsine square-root transformed for analysis. For each year's experiment, a 2-factor ANOVA with factors Site and Density was conducted with site as a random factor.

Table 1. Sediment characteristics (clay, silt, sand, organic matter) and salinity at sites used in the seed experiments. Salinity data for Chesapeake Bay sites from Chesapeake Bay Program Water Quality Monitoring Program (CBP 2001), for Chincoteague Bay from US National Park Service, and for South Bay from Virginia Institute of Marine Science Wachapreague Laboratory

\begin{tabular}{|c|c|c|c|c|c|}
\hline Site & $\%$ Sand $( \pm \mathrm{SD})$ & $\%$ Clay $( \pm \mathrm{SD})$ & $\%$ Silt $( \pm \mathrm{SD})$ & $\%$ Organic $( \pm \mathrm{SD})$ & Salinity (range) \\
\hline Chincoteague Bay & $95.98(0.42)$ & $2.96(0.96)$ & $1.06(0.76)$ & $0.57(0.02)$ & $26.9(24.7-29.7)$ \\
\hline Eastern Bay & $97.37(0.79)$ & $1.85(0.12)$ & $0.78(0.83)$ & $0.57(0.03)$ & $13.8(9.9-15.1)$ \\
\hline Gloucester Point & $97.19(1.4)$ & $2.84(1.44)$ & $0.00(0.00)$ & $0.53(0.13)$ & $21.2(19.8-23.6)$ \\
\hline Honga River & $91.10(10.67)$ & $2.97(3.93)$ & $5.92(6.77)$ & $0.56(0.17)$ & $16.2(11.5-18.5)$ \\
\hline James River & $97.09(0.34)$ & $0.87(0.85)$ & $2.04(1.19)$ & $0.46(0.06)$ & $19.1(13.6-23.2)$ \\
\hline Lynnhaven River & $88.44(2.89)$ & $4.85(0.97)$ & $6.71(1.96)$ & $0.83(0.15)$ & $24.1(21.1-28.0)$ \\
\hline Magothy Bay & $92.82(2.02)$ & $4.34(0.79)$ & $2.84(1.24)$ & $0.73(0.23)$ & $27.3(24.0-35.0)$ \\
\hline Mumfort Island & $95.16(0.72)$ & $0.21(0.31)$ & $4.63(0.92)$ & $0.38(0.06)$ & $21.2(19.8-23.6)$ \\
\hline Rappahannock River & $97.36(0.23)$ & $1.87(0.24)$ & $0.76(0.32)$ & $0.67(0.04)$ & $18.0(17.2-18.5)$ \\
\hline Solomons Island & $96.55(1.05)$ & $0.19(0.33)$ & $3.26(1.27)$ & $0.63(0.03)$ & $14.7(9.5-16.6)$ \\
\hline South Bay Inshore & $82.69(6.27)$ & $7.53(3.62)$ & $9.78(2.64)$ & $1.03(0.23)$ & $27.3(24.0-35.0)$ \\
\hline South Bay Offshore & $85.3(1.24)$ & $6.76(0.41)$ & $7.94(0.98)$ & $0.93(0.12)$ & $27.3(24.0-35.0)$ \\
\hline St. Mary's River & $87.73(4.49)$ & $2.31(0.51)$ & $9.96(4.04)$ & $1.03(0.24)$ & $15.4(11.9-17.7)$ \\
\hline
\end{tabular}


The data satisfied the assumptions for ANOVA (Zar 1996). Following a significant ANOVA, a Student-Newman-Keuls (SNK) post hoc multiple comparisons test was used to identify significantly differing sites.

\section{RESULTS}

The sediments at all sites were predominantly sand, with $<13 \%$ clay and silt (Table 1 ). The percent total organic matter was low, usually $1 \%$ or less (Table 1 ). Adult plant survivorship (percent of initial planting units surviving) was high at nearly all sites (31 to 99\% after $6 \mathrm{mo}$ ), indicating that water quality and sediment conditions at the experimental sites were adequate to support eelgrass growth. Germination of seeds under our laboratory setting was $66.5 \%$ in 1999 and $77.5 \%$ in 2000, similar to germination in previous trials (Orth et al. 1994, Fishman \& Orth 1996, Harwell \& Orth 1999, R. J. Orth unpubl. data), indicating that the seeds used in the experiment were viable. Salinity ranged from a mean of $13.8 \mathrm{psu}$ at Eastern Bay to $27.3 \mathrm{psu}$ at the South Bay site.

Seedlings were present in most plots analyzed in the 1999 and 2000 seed-density analysis, and ranged from 0.6 to $15.4 \%$ of the number of seeds initially released in 1999, and from 3.3 to $9.0 \%$ in 2000 , except for the lowest density treatment at South Bay where seedling success was $23.3 \%$. Only 5 plots in 2000 had no seedlings, all of which were 10 -seed treatments. Only

Table 2. Results of 2-factor ANOVA comparing Zostera marina seedling counts in $4 \mathrm{~m}^{2}$ plots with 1000 or 5000 seeds at 8 sites in 1999

\begin{tabular}{|lccrrrrr|}
\hline \multirow{2}{*}{ Parameter } & \multicolumn{2}{c}{ Effect } & \multicolumn{2}{c}{ Error } & $F$ & $p$ \\
& df & MS & df & MS & & \\
\hline Site & 7 & 0.0752 & 32 & 0.0025 & 29.521 & 0.000 \\
Density & 1 & 0.0050 & 7 & 0.0027 & 1.863 & 0.214 \\
Site $\times$ Density & 7 & 0.0027 & 32 & 0.0025 & 1.055 & 0.414 \\
& & & & & & \\
\hline
\end{tabular}

Table 3. Results of 2-factor ANOVA comparing Zostera marina seedling counts in $4 \mathrm{~m}^{2}$ plots with $10,100,1000$ or 5000 seeds at 4 sites in 2000

\begin{tabular}{|lccrccc|}
\hline \multirow{2}{*}{ Parameter } & \multicolumn{2}{c}{ Effect } & \multicolumn{2}{c}{ Error } & $F$ & $p$ \\
& df & MS & df & MS & & \\
\hline Site & 3 & 0.0639 & 31 & 0.0108 & 5.908 & 0.003 \\
Density & 3 & 0.0019 & 9 & 0.0188 & 0.099 & 0.959 \\
Site $\times$ Density & 9 & 0.0188 & 31 & 0.0108 & 1.739 & 0.122 \\
\hline
\end{tabular}

1 seedling was observed in the 12 control plots in 2000, and visual inspection of all 2000 plots revealed few, if any, seedlings outside the treatment plots. Almost all our previous dispersal experiments have shown limited transport of seeds broadcast on the sediment surface (Orth et al. 1994, Harwell \& Orth 1999). While we noted some seed movement in several seed-density treatments at Gloucester Point, 93.4\% of all seedlings observed were found within the original $4 \mathrm{~m}^{2}$ plot in which the seeds were dispersed; in $100 \mathrm{~m}^{2}$ plots, $87.3 \%$ were within the plot. Almost all the remaining seedlings that were not inside the plot were found within $4 \mathrm{~m}$ of the plot; divers rarely observed any seedlings outside this area.

There was no significant effect of seed-density in $4 \mathrm{~m}^{2}$ plots $(1999: \mathrm{p}=0.214 ; 2000: \mathrm{p}=0.958)$ in 1999 or 2000, but a significant site effect in both years (1999: $\mathrm{p}=0.000 ; 2000: \mathrm{p}=0.002$ ) (Tables $2 \& 3$; Figs. $2 \& 3$ ) There was no significant interaction effect in either year $(1999: \mathrm{p}=0.414 ; 2000: \mathrm{p}=0.121)$. In the $100 \mathrm{~m}^{2}$ plots, the number of seedlings within the measured area $\left(324 \mathrm{~m}^{2}\right)$ ranged from 4.3 to $13.9 \%$ of the initial number of seeds released (Table 4 ).

In both the large plots and in the higher density treatments of the small plots, we occasionally observed extremely high seedling densities in very small areas within the plots (up to 100 seedlings within $100 \mathrm{~cm}^{2}$ clumps). Most of the seedlings in these clumps had only 1 or 2 shoots seedling ${ }^{-1}$ compared with 5 to 8 shoots seedling ${ }^{-1}$ for more isolated seedlings in the rest of the plot area (R. J. Orth pers. obs.).

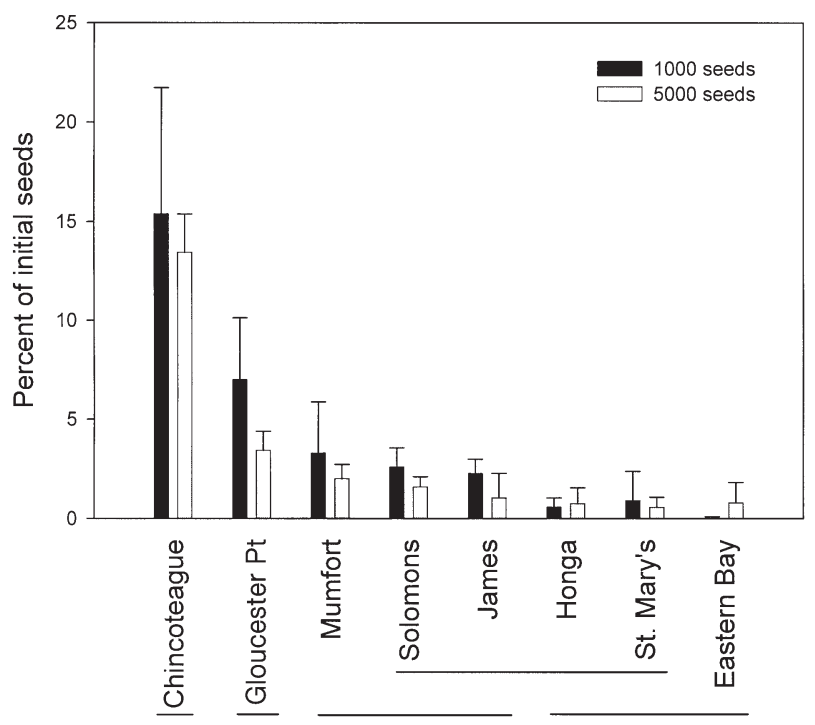

Fig. 2. Mean (+1 SD) number of Zostera marina seedlings in 1000 and 5000 seed-density treatments in $4 \mathrm{~m}^{2}$ plots in 1999 . Horizontal lines indicate sites that were not significantly different (SNK post-hoc multiple comparison test) 


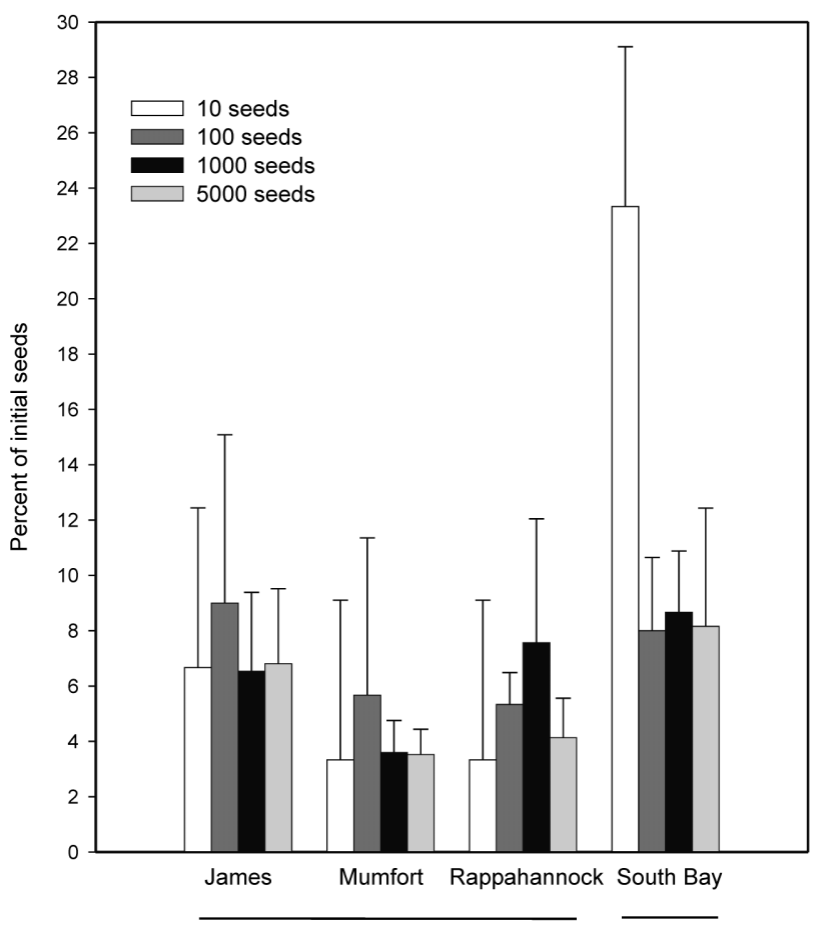

Fig. 3. Mean (+1 SD) number of Zostera marina seedlings in $10,100,1000$ and 5000 seed-density treatments in $4 \mathrm{~m}^{2}$ plots in 2000. Horizontal lines indicate sites that were not significantly different (SNK post-hoc multiple comparison test)

Table 4. Total number of Zostera marina seedlings developing from 50000 seeds in $100 \mathrm{~m}^{2}$ plots in 2000

\begin{tabular}{|lcc|}
\hline Site & $\begin{array}{c}\text { Total \# } \\
\text { seedlings }\end{array}$ & $\begin{array}{c}\text { Percent of } \\
50 \text { 000 seeds }\end{array}$ \\
\hline James River & 6921 & 13.8 \\
Rappahannock River & 2333 & 4.7 \\
South Bay offshore & 3237 & 6.5 \\
South Bay inshore & 2127 & 4.3 \\
Magothy Bay & 5147 & 10.3 \\
Lynnhaven River & 2352 & 4.7 \\
\hline
\end{tabular}

\section{DISCUSSION}

From the moment of a seed's release to its establishment as a seedling at a 'safe site', it must pass through an environmental 'sieve' (Harper 1977). This 'sieve' represents the sum of different processes (e.g. speciesspecific germination requirements) operating at the scale of the seed at that site that eventually determines whether a seedling will emerge. The results of the seed-addition experiments provide some insights into how Harper's (1977) environmental 'sieve' may operate in a seagrass system in the Chesapeake Bay region. First, our results support the conclusions of terrestrial studies in that few seeds actually establish as seedlings
(Harper 1977, Cook 1979, Cabin et al. 2000). Second, we did not detect a significant density-dependent effect on seed germination and initial seedling establishment. Third, we noted a significant site effect each year, suggesting that the processes regulating the proportion of seeds germinating are site-specific. Lastly, the percentage of seedlings in the $100 \mathrm{~m}^{2}$ plots (4.3 to $13.9 \%$ ) was similar to that in the smaller plots ( 3.3 to $23.3 \%$ ), suggesting that, within the size range examined, such processes are not likely to be scale-dependent.

It thus appears that density-dependence is not a significant issue in seed germination and initial establishment in Zostera marina systems in Chesapeake Bay, although the terrestrial literature has reported conflicting evidence. Unlike their laboratory results, Waite \& Hutchings $(1978,1979)$ found no density-dependence in field experiments with Plantago coronopus, but Cabin et al. (2000) found strong density-dependence in seed-predation experiments with the desert mustard Lesquerella fendleri.

Seed predation is pervasive and significant in the terrestrial environment (Janzen 1971), and has been shown to be important in several seagrass studies (Wassenberg \& Hill 1987, Wigand \& Churchill 1988, Wassenberg 1990, O'Brien 1994, Fishman \& Orth 1996, Holbrook et al. 2000, Orth et al. 2002). One mechanism employed by plants to escape predation is to produce seed abundances high enough to satiate a seed predator. While we did not directly measure predator density or behavior, the conclusion that initial seedling success was not affected by seed-density or total abundance indicates that seed predation was unlikely to have played an important role. Thus, predation on seeds (as demonstrated by Fishman \& Orth [1996] in a series of predator enclosure and exclosure experiments) may have inconsistent effects on seedling recruitment if potential seed predators are absent or scarce, or if a predator alters its behavior in response to preferred food availability. Potential seed predators noted in previous seagrass studies such as decapod crustaceans (crabs, shrimps, hermit crabs: Wassenberg \& Hill 1987, Wigand \& Churchill 1988, Wassenberg 1990, O'Brien 1994, Fishman \& Orth 1996, Holbrook et al. 2000) were observed at our sites, but almost all of these are opportunistic omnivores that prefer animal tissue over plant tissue, as evidenced by feeding-habit studies (Laughlin 1982, Hines et al. 1990).

This study does not support the hypothesis that seedling-seedling interactions reduce germination rates. Observations of extremely high seedling abundance in small clumps (up to 100 seedlings in areas as small as $100 \mathrm{~cm}^{2}$ ) demonstrate that germination occurs even at the highest of seed-densities (Granger et al. 2000). Instead, these clumps may imply that hydrodynamics play an important role in transporting and 
concentrating seeds at 'safe sites'. While we do not have a complete understanding of what constitutes a 'safe site' in our system, we suggest that 'safe sites' may be related to the topography of the bottom. When seeds are rolled along the bottom by tides and currents, they become lodged against some discontinuity in the sediment surface, and eventually get buried. Harper et al. (1965) found positive relationships between seed germination and soil surface heterogeneity for several terrestrial species. Flume experiments on prepared, smooth sand have found that surface relief as little as $1 \mathrm{~mm}$ high could stop a Zostera marina seed from rolling (Orth et al. 1994). Micro-sites could be formed hydrodynamically or by benthic infaunal species through bioturbation or burrowing activities (Rhoads \& Young 1970, Rhoads 1974). Luckenbach \& Orth (1999) found that increasing densities of the infaunal polychaete Clymenella torquata caused increased retention of $Z$. marina seeds by enhancing the vertical relief of the sediment surface through feeding and defecation. Mobile fauna such as decapod crustaceans can create small grooves on the sediment surface as they move, by pushing their appendages into the sediment and creating deformities large enough to trap seeds. The relative influence of these biotic and abiotic mechanisms in creating 'safe sites' remains a topic for future studies but may be key to understanding the rates of seed survival.

Although these observations do not show reduced germination in dense clumps, the ultimate survival rate of the small, dense clumps of Zostera marina seedlings remains in doubt. Seedling competition can result in much lower seedling survival when closely spaced seedlings compete for limiting resources (Harper 1977). Granger et al. (2000) followed laboratorygerminated seeds of $Z$. marina and recorded a reduction in shoots per seedling in experimental treatments that had high densities of germinated seeds. In this study, the few shoots per seedling in dense clumps compared to the higher numbers of shoots per seedling in less dense areas (R. J. Orth pers. obs.) supports the hypothesis that these seedlings were resource-limited, and raises the question as to whether the shoot densities that would eventually develop in these clumps would be lower than the densities observed after initial seedling establishment. Investigations into the effect of high seedling densities on ultimate shoot density are the next logical research step.

Our germination data, in conjunction with recently published data on the long-distance dispersal potential of Zostera marina via rafting of reproductive shoots containing viable seeds (Harwell \& Orth 2002a, Reusch 2002), provide insights into the seed-delivery rates necessary to form the patches of seedlings observed each spring in areas at varying distances from source populations in the Chesapeake Bay region (Harwell \&
Orth 2002a, R. J. Orth pers. obs.). Reusch (2002) recorded $Z$. marina seed-densities of $1340 \mathrm{~m}^{-1}$ shoreline in reproductive shoots washed up in beach detrital wrack and, based on genetic microsatellite data, calculated that 130 seeds $\mathrm{m}^{-1}$ shoreline came from distant locations. Harwell \& Orth (2002a) also found up to 31 viable $Z$. marina seeds in $20 \mathrm{~cm}$ diameter detrital patches $\left(987\right.$ seeds $\mathrm{m}^{-2}$ ) along a $34 \mathrm{~km}$ stretch of shoreline in Chesapeake Bay. Based on the seed-densities in beach detritus, noted by Reusch (2002) and Harwell \& Orth (2002a), it appears that there is the potential for a high delivery rate of seeds to areas distant from source populations. Given the germination rates observed in our experiments, we believe that rafting reproductive shoots transport adequate numbers of seeds to establish new patches at distant sites determined by winds and currents. The data also imply that seed supply rather than micro-site availability may be the primary factor preventing re-colonization of unvegetated sites that have adequate water quality (Eriksson \& Ehrlen 1992, Dennison et al. 1993, Harwell \& Orth 2002a, Reusch 2002). Future work on the relative roles of these 2 processes should include the use of seed traps that collect both rafting shoots and seeds.

The apparent lack of density-dependent germination observed in our study combined with recent data on seed dispersal (Harwell \& Orth 2002a, Reusch 2002) and patch dynamics (Olesen \& Sand-Jensen 1994) provides valuable information for seagrass conservation and restoration strategies. Since established beds may be important sources of seeds that ultimately create new patches at distant sites (Hanski 1982, Harwell \& Orth 2002a), protection of existing beds (regardless of size or density) as a source of propagules needs careful consideration. Also, while almost all restoration work to date has been conducted with adult plants (Fonseca et al. 1998), successful establishment of seedlings during the present study suggests that seeds should be considered as a viable alternative or addition in future projects. Although there was no consistent densityeffect on germination, further work is needed to understand shoot-shoot interactions so that restoration projects can optimize seed dispersal, thus achieving the highest proportional seedling survival.

Acknowledgements. We thank D. Combs, S. Everett, A. Tillman, and J. van Montfrans for field assistance. Emmett Duffy provided helpful comments on the draft manuscript. This work was funded by Virginia's Recreational Fishing License Fund and Virginia's Coastal Resource Management Program, administered by the Department of Environmental Quality of the National Oceanic and Atmospheric Administration, Office of Ocean and Coastal Resource Management, under the Coastal Zone Management Act of 1972, as amended. This manuscript is contribution no. 2531 from the Virginia Institute of Marine Science. 


\section{LITERATURE CITED}

Cabin RJ, Marshall DL, Mitchell RJ (2000) The demographic role of soil seed banks. II. Investigations of the fate of experimental seeds of the desert mustard Lesquerella fendleri. J Ecol 88:293-302

Chambers JC, MacMahon JA (1994) A day in the life of a seed: movements and fates of seeds and their implications for natural and managed systems. Annu Rev Ecol Syst 25: 263-292

Churchill AC (1983) Field studies on seed germination and seedling development in Zostera marina L. Aquat Bot 16: 21-29

Cook RE (1979) Patterns of juvenile mortality and recruitment in plants. In: Solibrig OT, Jain S, Johnson GB, Raven PH (eds) Topics in plant population biology. Columbia University Press, New York, p 207-231

Crawley MJ (1992) Seed predators and plant populations. In: Fenner M (ed) Seeds: the ecology of regeneration in plant communities. CAB International, Wallingford, p 157-191

Crawley MJ, Long CR (1995) Alternate bearing, predator satiation and seedling recruitment in Quercus robur L. J Ecol 83:683-696

den Hartog C (1970) The sea-grasses of the world. NorthHolland, Amsterdam

Dennison WC, Orth RJ, Moore KA, Stevenson JC, Carter V, Kollar S, Bergstrom PW, Batiuk RA (1993) Assessing water quality with submersed aquatic vegetation. BioScience 43 : 86-94

Eriksson O, Ehrlen J (1992) Seed and microsite limitation of recruitment in plant populations. Oecologia 91:360-364

Ewanchuk PJ, Williams SL (1996) Survival and re-establishment of vegetative fragments of eelgrass (Zostera marina). Can J Bot 74:1584-1590

Fishman JR, Orth RJ (1996) Effects of predation on Zostera marina L. seed abundance. J Exp Mar Biol Ecol 198:11-26

Folk RL (1980) Petrology of sedimentary rocks. Hemphill Publishing Company, Austin, TX

Fonseca MS, Kenworthy WJ, Thayer GW (1998) Guidelines for the conservation and restoration of seagrasses in the United States and adjacent waters. NOAA Coastal Ocean Program Decision Analysis Series No. 12. NOAA Coastal Ocean Office, Silver Spring, MD

Granger SL, Traber MS, Nixon SW (2000) The influence of planting depth and density on germination and development of Zostera marina L. seeds. Biol Mar Méditerr 7: 55-58

Hanski I (1982) Dynamics of regional distribution: the core and satellite species hypothesis. Oikos 38:210-221

Harper JL (1977) Population biology of plants. Academic Press, London

Harper JL, Williams JT, Sagar GR (1965) The behavior of seeds in soil. 1. The heterogeneity of soil surfaces and its role in determining the establishment of plants from seed. J Ecol 53:273-286

Harrison PG (1993) Variations in demography of Zostera marina and $Z$. noltii on an intertidal gradient. Aquat Bot 45:63-77

Harwell MC, Orth RJ (1999) Eelgrass (Zostera marina L.) seed protection for field experiments and implications for large scale restoration. Aquat Bot 64:51-61

Harwell MC, Orth RJ (2002a) Long distance dispersal potential in a marine macrophyte. Ecology 83:3319-3330

Harwell MC, Orth RJ (2002b) Seed bank patterns in Chesapeake Bay eelgrass (Zostera marina): a bay-wide perspective. Estuaries 25:1196-1204
Hines AH, Haddon AM, Wiechert LA (1990) Guild structure and foraging impact of blue crabs and epibenthic fish in a subestuary of Chesapeake Bay. Mar Ecol Prog Ser 67: $105-126$

Holbrook SJ, Reed DC, Hansen K, Blanchette CA (2000) Spatial and temporal patterns of predation on seeds of the surfgrass Phyllospadix torreyi. Mar Biol 136:739-747

Hulme PE (1994) Post-dispersal seed predation in grassland: its magnitude and sources of variation. J Ecol 82: $645-652$

Janzen DH (1971) Seed predation by animals. Annu Rev Ecol Syst 2:465-492

Laughlin RA (1982) Feeding habits of the blue crab Callinectes sapidus Rathbun in the Apalachicola estuary, Florida. Bull Mar Sci 32:807-822

Luckenbach MW, Orth RJ (1999) Effects of a deposit-feeding invertebrate on the entrapment of Zostera marina L. seeds. Aquat Bot 62:235-247

Marone L, Horno ME, del Solar RG (2000) Post-dispersal fate of seeds in the Monte desert of Argentina: patterns of germination in successive wet and dry years. J Ecol 88: 940-949

Moore KA, Orth RJ, Nowak JF (1993) Environmental regulation of seed germination in Zostera marina L. (eelgrass) in Chesapeake Bay: effects of light, oxygen and sediment burial. Aquat Bot 45:79-91

O'Brien CJ (1994) Ontogenetic changes in the diet of juvenile brown tiger prawns Penaeus esculentus. Mar Ecol Prog Ser 112:195-200

Olesen B (1999) Reproduction in Danish eelgrass (Zostera marina L.) stands: size-dependence and biomass partitioning. Aquat Bot 65:209-219

Olesen B, Sand-Jensen K (1994) Patch dynamics of eelgrass Zostera marina. Mar Ecol Prog Ser 106:147-156

Orth RJ, Moore KA (1984) Distribution and abundance of submerged aquatic vegetation in Chesapeake Bay: an historical perspective. Estuaries 7:531-540

Orth RJ, Luckenbach MW, Moore KA (1994) Seed dispersal in a marine macrophyte: implications for colonization and restoration. Ecology 75:1927-1939

Orth RJ, Harwell MC, Fishman JR (1999a) A rapid and simple method for transplanting eelgrass using single, unanchored shoots. Aquat Bot 64:77-85

Orth RJ, Nowak JF, Wilcox DJ, Whiting JR, Nagey LS (1999b) Distribution of submerged aquatic vegetation in the Chesapeake Bay and tributaries and Chincoteague Bay1998. Final Report, US Environmental Protection Agency, Annapolis, MD

Orth RJ, Harwell MC, Bailey EM, Bartholomew A and 5 others (2000a) Factors influencing the germination of seagrass seeds: a review and emerging issues. Mar Ecol Prog Ser 200:277-288

Orth RJ, Wilcox DJ, Whiting JR, Nagey LS, Fishman JR (2000b) Distribution of submerged aquatic vegetation in the Chesapeake Bay and tributaries and Chincoteague Bay-1999. Final Report, US Environmental Protection Agency, Annapolis, MD

Orth RJ, Heck KL Jr, Tunbridge DJ (2002) Predation on seeds of the seagrass Posidonia australis in Western Australia. Mar Ecol Prog Ser 244:81-88

Reusch TBH (2002) Microsatellites reveal high population connectivity in eelgrass (Zostera marina) in two contrasting coastal areas. Limnol Oceanogr 47:78-85

Rhoads DC (1974) Organism-sediment relations on the muddy sea floor. Oceanogr Mar Biol Annu Rev 12: 263-300

Rhoads DC, Young DK (1970) The influence of deposit- 
feeding organisms on sediment stability and community trophic structure. J Mar Res 28:150-178

Silverton JW (1980) The evolutionary ecology of mast seeding in trees. Biol J Linn Soc 14:235-250

Turnbull LA, Crawley MJ, Rees M (2000) Are plant populations seed limited? A review of seed sowing experiments. Oikos 88:225-238

Waite S, Hutchings MJ (1978) The effects of sowing density, salinity and substrate upon the germination of Plantago coronopus L. New Phytol 81:341

Waite S, Hutchings MJ (1979) A comparative study of establishment of Plantago coronopus L. from seeds sown randomly and in clumps. New Phytol 82:575-583

Wassenberg TJ (1990) Seasonal feeding on Zostera capricorni

Editorial responsibility: Kenneth Heck (Contributing Editor), Dauphin Island, Alabama, USA seeds by juvenile Penaeus esculentus (Crustacea: Decapoda) in Moreton Bay, Queensland. Aust J Mar Freshw Res 41:301-310

Wassenberg TJ, Hill BJ (1987) Natural diet of tiger prawns Penaeus esculentus and Penaeus semisulcatus. Aust J Mar Freshw Res 13:85-92

Wenny DG (2000) Seed dispersal, seed predation, and seedling recruitment of a neotropical montane tree. Ecol Monogr 70:331-351

Wigand C, Churchill AC (1988) Laboratory studies on eelgrass seed and seedling predation. Estuaries 11: 180-183

Zar JH (1996) Biostatistical analysis, 3rd edn. Prentice-Hall, Upper Saddle River, NJ

Submitted: April 5, 2002; Accepted: December 5, 2002

Proofs received from author(s): February 28, 2003 